\title{
Molasses as a new nutrition medium for Scenedsmus quadricauda growth and production of some bio compounds
}

Yousef J.I. AL -Shahery, Israa N. AL- Asady

DOI. 10.21931/RB/2021.06.04.11

Abstract: Algae comprise a large group of Thallophyta, which may be used as direct nutrition of human beings. Molasses is the by-product of the sugar manufacturing facility. In this study, a locally isolated Scendsmus quadricauda from the environment of Mosul in the Shalalat region was obtained. Biomass of Scenedsmus was measurement by carried out and filtration then drying in an oven for $24 \mathrm{~h}$ and weighed, Estimation of chlorophyll and protein and carbohydrate content of Scenedsmus. The research has proved that the best growing period for Scendsmue quadricauda is 15 days when using sugar factory waste as a carbon source, the growth reached $(1.42 \mathrm{~nm}$ ) as optical density, biomass (1525 mg /L), chlorophyll (green), pigment (18 mg /l) protein content $(396 \mathrm{mg} / \mathrm{l}$ ) and carbohydrates ( $501 \mathrm{mg} / \mathrm{l}$ ). The research showed that the use of sugar factory waste as a nutritional medium for algal growth in the dark (11.5\%) achieved good growth of Scendesmues quadricauda ( $0.632 \mathrm{~nm}$ ), biomass (820 mg / L), green pigment (Chlorophyll) (18 mg /L) protein content (235 mg / L ) and carbohydrates (401 mg/L). while using phosphor $(0.018 \%)$ of K2HPO4 in dark medium achieved highest growth rate $(0.91 \mathrm{~nm})$, biomass $(1110 \mathrm{mg} / \mathrm{L})$ chlorophyll ( $22 \mathrm{mg} / \mathrm{L})$ protein $(301 \mathrm{mg} / \mathrm{L})$ and carbohydrate $(461 \mathrm{mg} / \mathrm{L})$. It is noted too, that using IAA $(0.5 \mathrm{~g} / \mathrm{L})$ in dark medium support best growth $(0.888 \mathrm{~nm})$, biomass $(1010 \mathrm{mg} / \mathrm{L})$ chlorophyll $(25 \mathrm{mg} / \mathrm{L})$, protein $(230 \mathrm{mg} / \mathrm{L})$ and carbohydrate $(440 \mathrm{mg} / / \mathrm{L})$. The study showed that thiamine $(1 \mathrm{~g} / \mathrm{L})$ in dark medium achieved highest growth $(0.750 \mathrm{~nm})$ biomass $(218 \mathrm{mg} / \mathrm{L})$, chlorophyll $(29 \mathrm{mg} / \mathrm{L})$, protein (220 mg/L), carbohydrate (340mg/L). Therefore, using Molasses can enhance the growth, biomass, chlorophyll, protein, and carbohydrate content in the $S$. quadricauda.

Key words: Scenedsmus quadricauda, Chlorophyll contents, Molasses, Biomass.

\section{Introduction}

Algae can grow in different aquatic environments, whether fresh or salty water. These organisms are used as food for human beings to fulfill the increasing needs of nutrition due to the increase of population and malnutrition facing people in some regions of the world ${ }^{1}$.

Also, many studies were carried out on the possibility of using algae for the natural environment to eliminate waste from factories, health centers, educational institutions. Algae can exploit the various wastes produced from the above sources and benefit from them in producing abundant algal growth, which is used as animal feed. Thus achieving two important objectives, ridding the local environment of the danger of industrial and productive pollutants, as well as exploiting these wastes as they are cheap basic materials to produce abundant algal growth ${ }^{2,3}$.

Several research and references have indicated the possibility of switching algae from Autotrophic to Heterotrophic ${ }^{4,5}$, indicated that some green algae could grow in heterotrophic medium, and (6), indicated that algae could exploit organic wastes as a medium for their growth. Molasses is a by-product of sugar manufacturing processes ${ }^{4,7}$.

The current study aims to isolate and cultivate a local strain of green algae S. quadricauda. And its ability to exploit the wastes of the sugar manufacturing factory as a nutrition medium for growth.

\section{Materials and methods}

\section{Isolation and preservation of algae}

In this study, an isolate of S.quadricauda was obtained from the Iraqi environment (Shalalat region). S.quadricauda was cultured in modified Ch10 medium ${ }^{8}$, that consists of the following components: $0.4 \mathrm{gm} / \mathrm{L} \mathrm{Ca}\left(\mathrm{NO}_{3}\right)_{2}, 0.1 \mathrm{gm} / \mathrm{L} \mathrm{K}_{2} \mathrm{HPO}_{4^{\prime}}$ $0.2 \mathrm{gm} / \mathrm{L} \mathrm{Na}_{2} \mathrm{CO}_{3}, 0.25 \mathrm{gm} / \mathrm{L} \mathrm{MgSO}{ }_{4} 7 \mathrm{H}_{2} \mathrm{O}, 0.25 \mathrm{gm} / \mathrm{L} \mathrm{Na}_{2} \mathrm{SiO}_{3}{ }^{\prime}$ and $0.05 \mathrm{gm} / \mathrm{L}$ Ammonium Ferric-- figure $(1,2)$.

The daily growth rate was measured using a spectrophotometer at $(436 \mathrm{~nm})$ wavelength, and the biomass was weighed for volume $(100 \mathrm{~mL})$ of the culture ${ }^{9}$. The chlorophyll content, protein, and carbohydrates of alga were measured according to standard methods using spectrophotometry and specific wavelengths as described in the approved ${ }^{9,10}$.

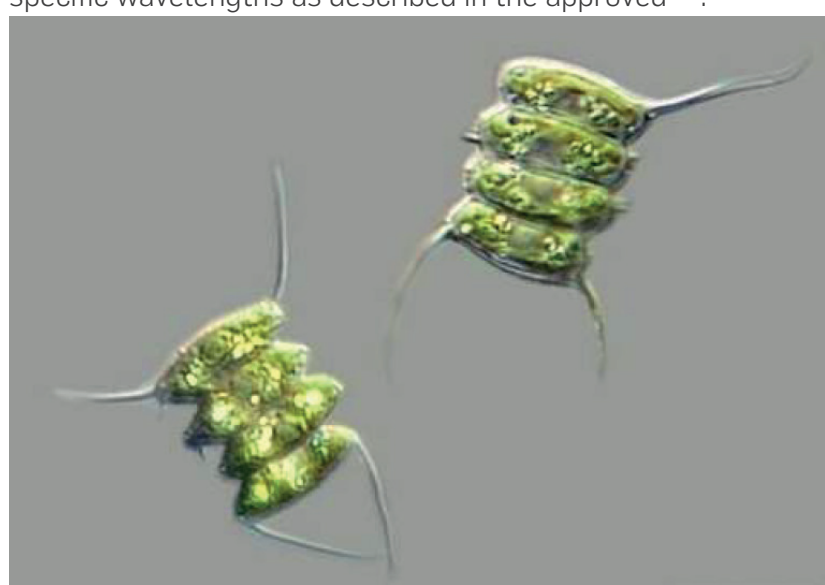

Figure 1. S. quadricanda microscopic picture magnification $40 \mathrm{X}$

\section{Results and discussion}

The effect of growth periods in sugar factory wastes on the vitality of cells Scendsmue. After seventeen days of cultivation (figure3), the best growth $(1.45 \mathrm{~nm})$ as optical densi- 


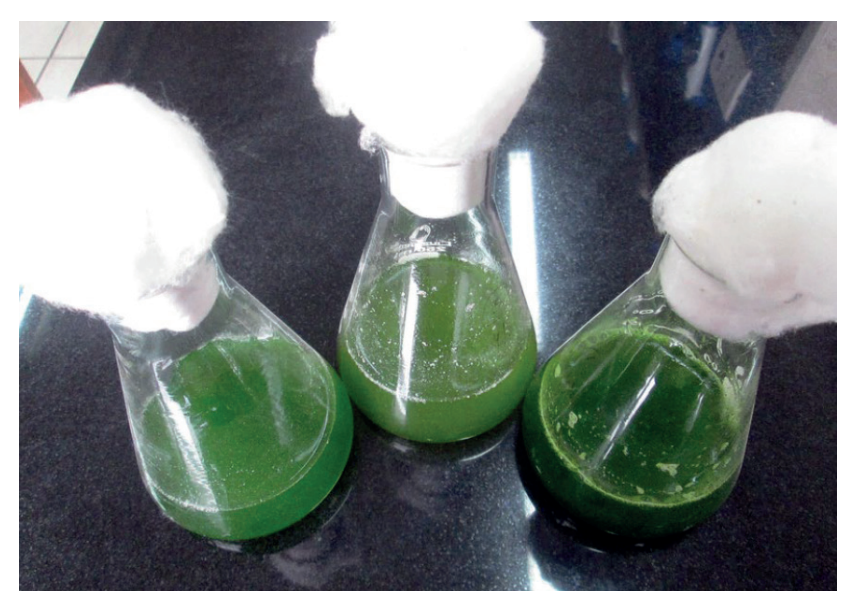

Figure 2. Pure cultures of algae S. quadricanda.

ty, biomass (1525 mg/L), green pigment (18 mg /L), protein content $(369 \mathrm{mg} / \mathrm{L})$, and carbohydrate content $(501 \mathrm{mg} / \mathrm{L})$ of the alga were reported on the fifteenth day of transplantation. Perez et al.(2010) noticed that the fifteen-day was the best period to obtain high growth and yield from the cells of some green algae and indicated the direct relationship between cell growth and vital components; this was confirmed by (11) while studying the photosynthesis of some algae. This is also shown by (12) since they noticed that number of cells correlates positively with the growth value of S. obliquus.

\section{The effect of different concentrations of sugar plant wastes on vitality $\mathcal{S}$. quadricuda alga.}

Algae depend on light in the manufacture of their food, and their conversion to feed throwing into the dark depends on the presence of carbohydrate sources ${ }^{11,12}$, The results ( figure 4 ) showed that the best growth of alga was achieved (1.601 $\mathrm{nm}$ ) and the best biomass weight ( $890 \mathrm{mg} / \mathrm{L}$ ) when using molasses at the concentration (11.5). The results showed that the best green pigment content was $(18 \mathrm{mg} / \mathrm{L})$, protein content ( $235 \mathrm{mg} / \mathrm{L}$ ), and carbohydrate content ( $401 \mathrm{mg} / \mathrm{L}$ ) when using concentrate ( $9.0 \%$ ) from sugar production plant wastes (molasses). Shah (2012) recorded the best growth of Chlorella sp. achieved when using monosaccharides with $(0.25 \%)$ under dark conditions, whereas 13 also showed the ability of microalga S. obliquse to exploit sources of sugar such as glucose and acetate for heterogeneous nutrition. However, (14) explains that using common cultivation conditions (light and dark) and in the presence of a carbon source stimulates algae Scenedesmues to produce high carbohydrates and protein.

\section{Effect of adding different concentrations of $\mathrm{K}_{2} \mathrm{HPO}$ on the vitality of alga $S$. quadricuda, which grows on sugar production plant wastes medium.}

The results (figure 5) indicated that the best growth of alga S. quadricauda was reached $(0.98 \mathrm{~nm})$, biomass weight (1220 $\mathrm{mg} / \mathrm{L}$ ), green pigment (22 mg/L ), protein content (299 mg/L), and carbohydrate content ( $461 \mathrm{mg} / \mathrm{L})$ when using a substance potassium thiophosphate at a concentration $(0.018 \%)$. The positive effect of phosphorous on algae growth indicates the significant role of this element in building many cellular organelles and biomolecules ${ }^{15}$. These came together with biomass results, chlorophyll, protein, and carbohydrate content ${ }^{16-19}$.

\section{Test the addition of different concentrations of IAA in} molasses medium on the vitality of alga $S$. quadricauda

IAA is a natural plant hormone that can be synthesized and has a vital role in the vitality and growth of plants in general, and many references indicated the ability of microalgae and cyanobacteria to produce IAA ${ }^{20}$.

The results showed (figure 6) that the best values were obtained for the growth of alga S. quadricauda (0.891 nm), the biomass (1022 $\mathrm{mg} / \mathrm{L})$, the best photosynthetic pigment (25 $\mathrm{mg} / \mathrm{L})$, protein content $(230 \mathrm{mg} / \mathrm{L})$, and carbohydrate content (440 mg/L) when adding IAA (0.5\%) prove ${ }^{21}$, The Scenedsmus $\mathrm{sp}$. and other microalgae is growth highest with the addition of IAA to the nutrient medium. Many studies have confirmed the relationship of IAA in stimulating algae growth, but the high concentration of IAA has an opposite focus on development and effectiveness ${ }^{22}$. A high concentration of IAA inhibits building up the photosynthetic pigment, protein, and carbohydrate content of algae Chlorella ${ }^{23}$.

\section{The effect of adding different concentrations of thiamine on the vitality of $S$. quadricauda in the dark.}

Vitamins are essential in the growth and activity of algae in general; many studies indicate the importance of adding some vitamins in specific concentrations in algae development media to support their growth and biomass production ${ }^{24,25}$.

The results indicated (figure 7 ) the best growth of S. quadricauda ( $0.766 \mathrm{~nm}$ ), the best value for biomass ( $218 \mathrm{mg} / \mathrm{L})$, the best content of the green pigment ( $28 \mathrm{mg} / \mathrm{L}$ ), the best protein $(220 \mathrm{mg} / \mathrm{L})$, and carbohydrate content $(340 \mathrm{mg} / \mathrm{L})$ where achieved in (0.01) thiamine concentration. (24) confirm the importance of adding thiamine in the medium microalgae growth. (25) indicated that a minimum of thiamin, ascorbic acid ( 40 _ $80 \mathrm{mg} / \mathrm{L}$ ) have an essential role in increasing the content of the photosynthetic pigment, protein, and carbohydrate content. Vitamin thiamine has a strong position and relationship in building amino acids ${ }^{10}$.

\section{Conclusions}

The study proved that the local isolate of S. quadricauda alga could exploit the industrial wastes of the sugar production plant (molasses) to grow and produce biomass and thus rid the environment of industrial pollution with these wastes.

\section{Acknowledgment}

We thank the presidency of the University of Mosul for the facilities provided for the completion of this research.

\section{Bibliographic references}

1. AL-Shahery. Y.J. and ALasady, I.N. (2021). Identification of saturated and unsaturated fatty acids produced by chlorella vulgaras as a potential candidate for biodiesel production. Trop. J. Nat. Prod. Res . , 5 ( 2 ) 238 -242.

2. AL- Shakarchi, H. K. and AL- shahery, Y.J. ( 2020 ) Evaluation of Arthrospira sp. growth ability on heavy metal salts and their effect on some cellular components. Periodico Tche Quimica, vol $17: 34$

3. Al-Obeidi, O.M.S. (2018). Testing of physical and chemical properties and their relation to the species variation of distribution algae in Duhok Dam- Duhok. M.Sc. thesis Dept. of Biology, Science College. Tikrit University.

4. Ali, R.H. (2017). Using remaining's of sugar production factory (Molasses) as culture medium and the effects of some culture conditions on growth and numbers of biological constituents for Chorella vulgaris alga. M.Sc. thesis Dept. of Biology, Science College. Mosul University. 

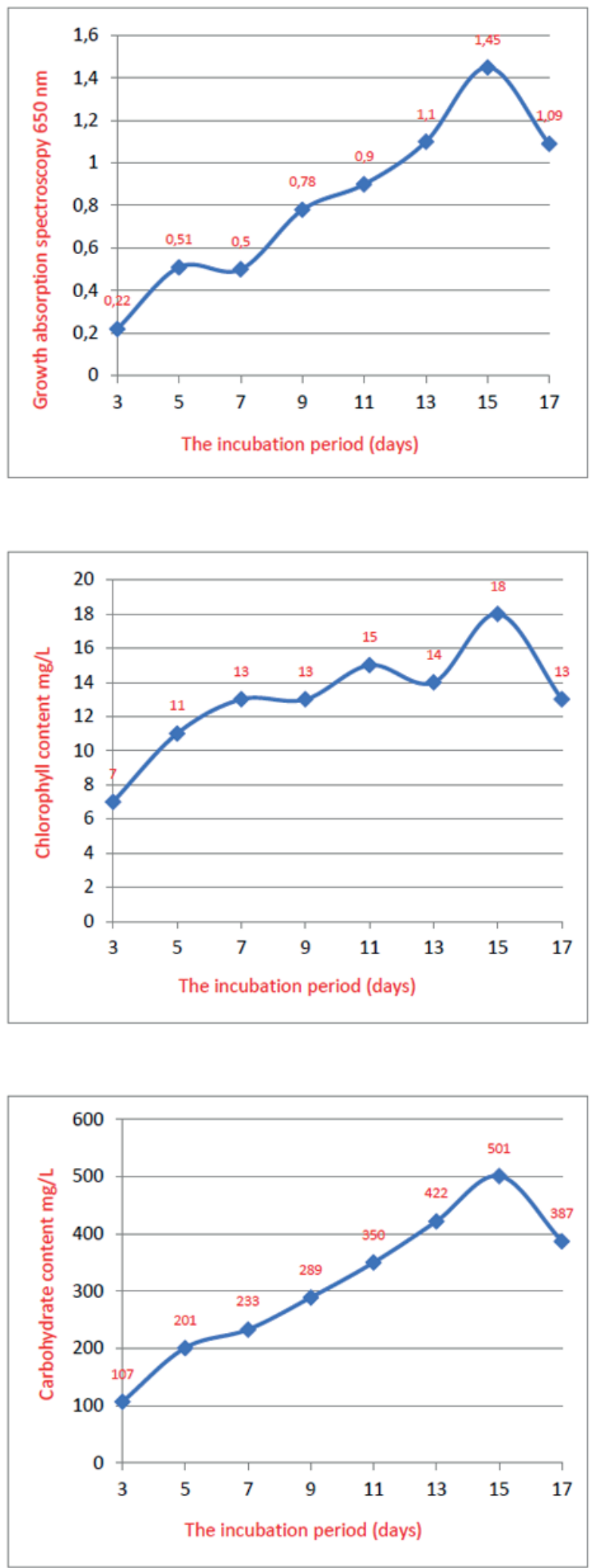

5. Shah, D. (2012). Effect of glucose supplementation on night time biomass loss and productivity of microalgae Chorella. cleve and state univ. India., 1:68.

6. Perez-Gracia, O.; de-Bashan, L.E.; Hernanadez, L.; Bashan, Y. (2010). Effictency of growth and nutrient uptake from waste water by heterotrophic, autotyophic and mixotrophic cultivation of Chlorella vulgaris immobilized Azospirilli umbrasilense. 3 phycol., 46: 800-812.
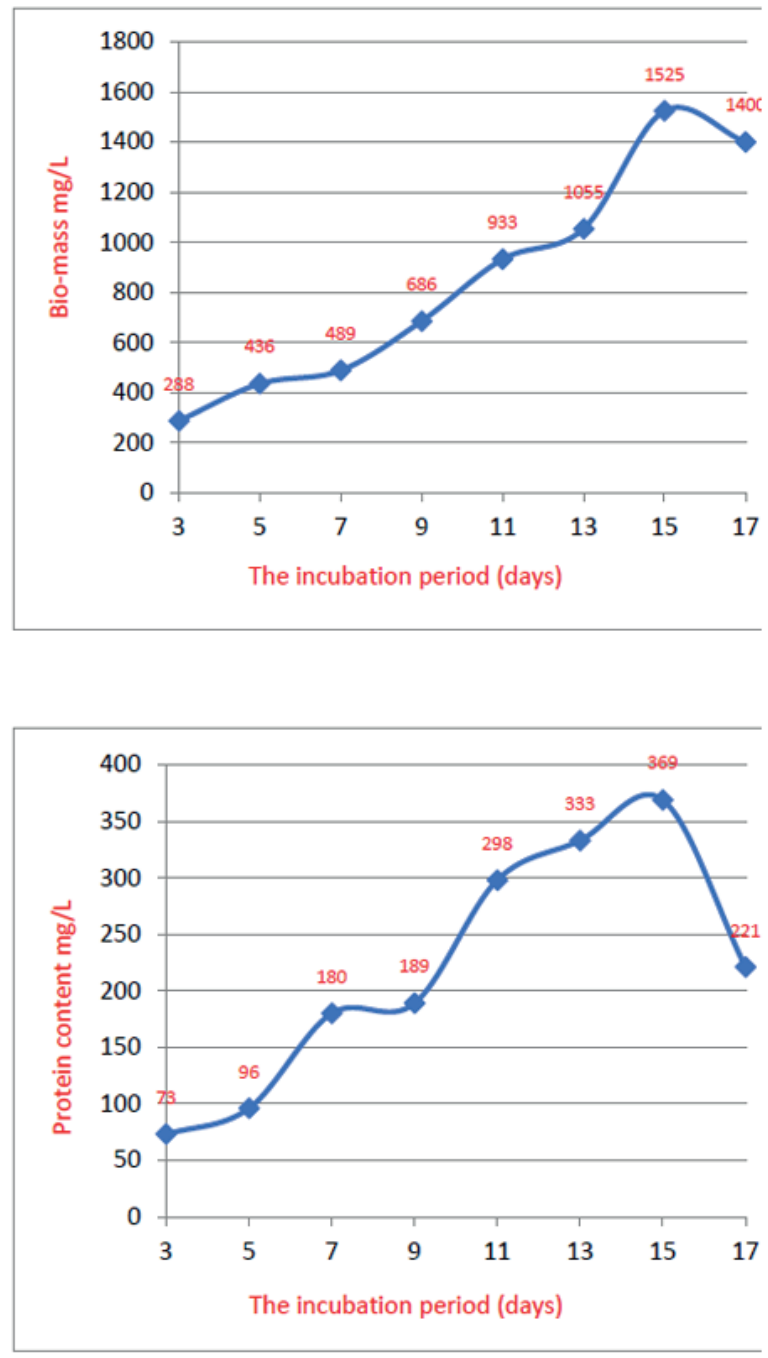

Figure 3. Influences the cultivation periods in the medium of sugar factory wastes on growth and photosynthesis pigment, protein, and carbohydrate content. Each value is an average of three frequencies.

7. Al-Khafaji, M.Sc. (2017). Microbial biotechnology (Molecular instruction). Biotechnology and engineering institute for higher studies. Baghdad University. Ministry of Higher Education and Scientific Research.

8. Al-Katib, M. (2017). M.A. (2017). Indol Acetic acid estimation some local Microalgae and its extraction, partial diagnostic from Gleocapsa sp. pp 7428. Ph.D. Thesis, Dept. of Biology, Eud. College, Mosul University. Iraq. 

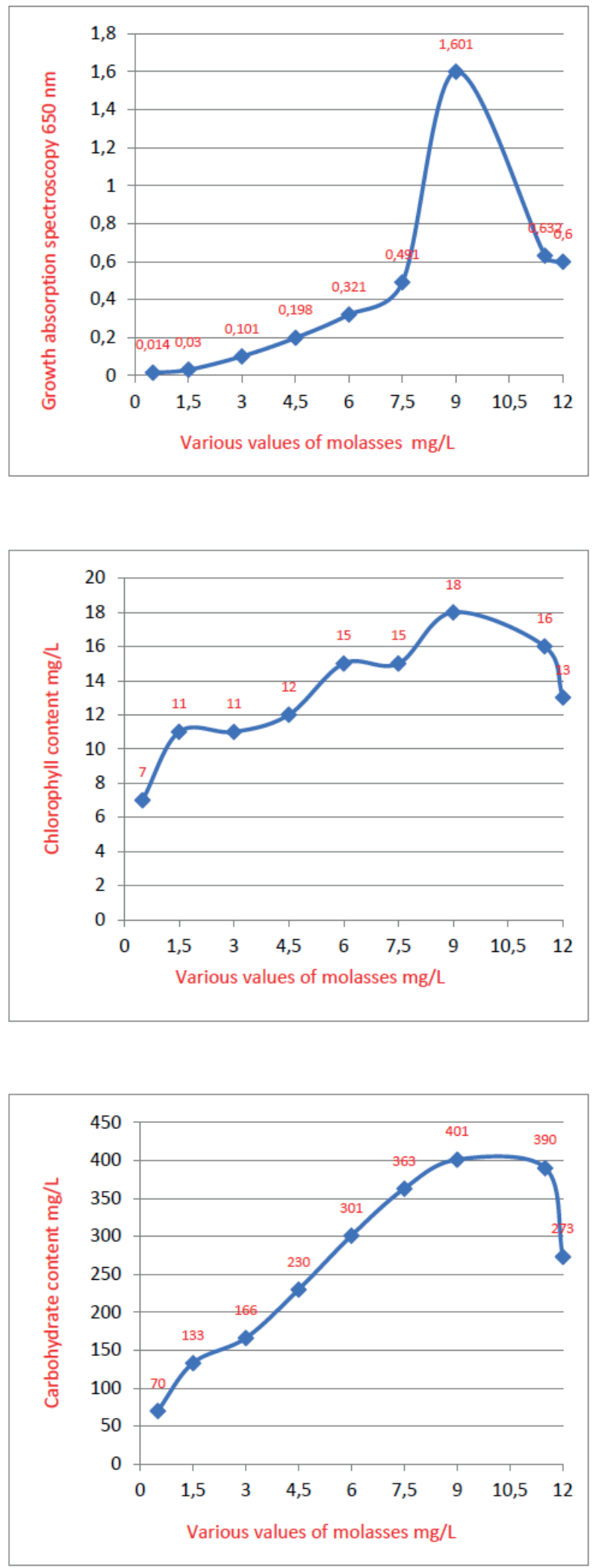

9. Al-Shandah, B. T.I.; Abd-Al-Jaber, R.A. and Farkha, K.J. (2017). Qualitative and quantitative study of alage in three drinking water plants supply springs in Sulaymaniyah province-Kurdistan region of Iraq. Tikrit Journal of pure science (6): 8-24

10. Mehrotra, S.; Verma, N. Shukla, A. and Mishra, B. (2013) Biochemistry. Third edition San-Francisco: Addison-Wesley --.

11. Andrea, V.; Fabrizio, D.; Roberta, S.; Pietro, A.and Agnese, G. (2017). Microalage cultivation for lipid and carbohydrates production. Chemical engineering transactions Vol. 57.
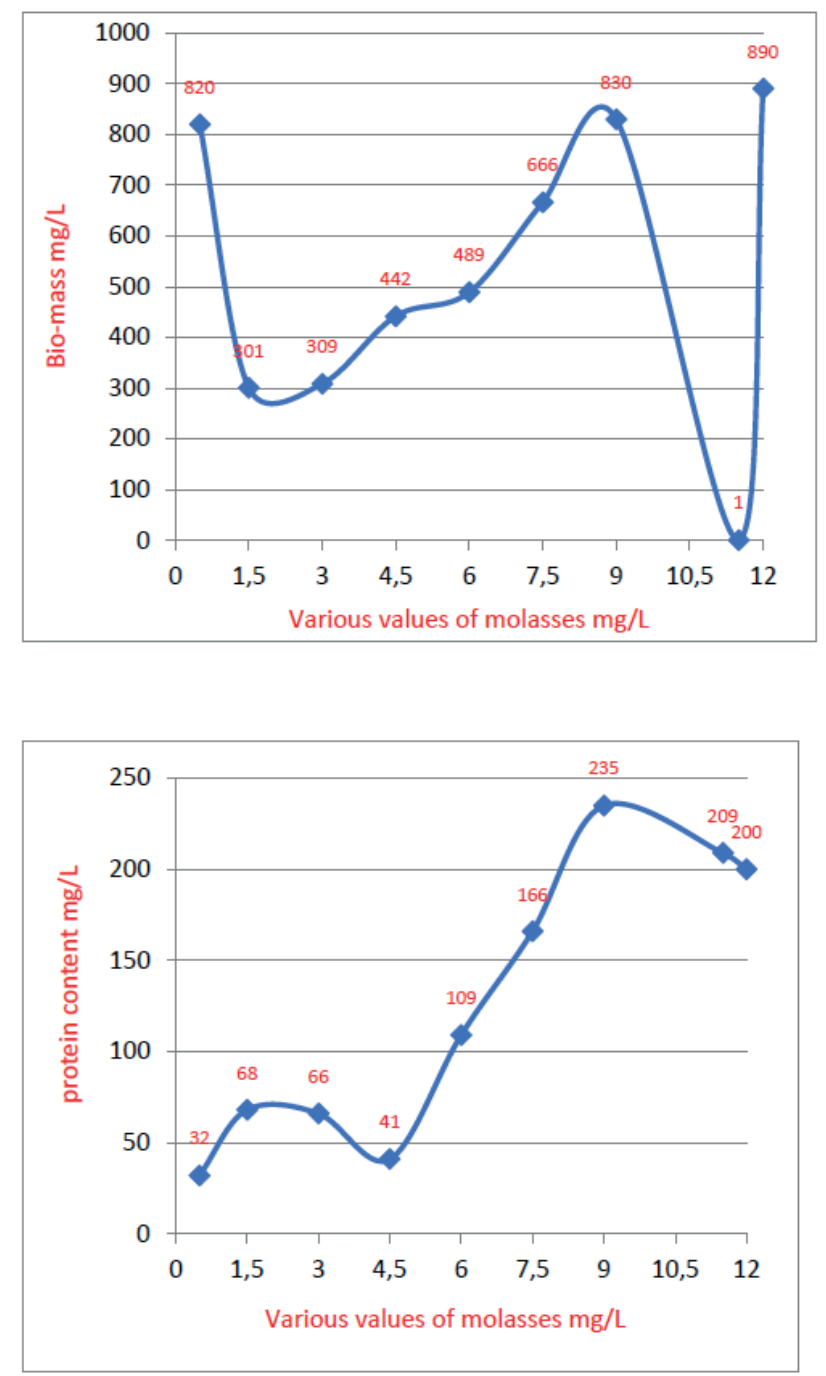

Figure 4. Influence of different concentrations of sugar factory wastes on the vitality of alga S. quadricuda in the dark. Each value is an average of three frequencies.

12. Emanuele, G.P.; Marcio, A.M.; Marana, D.S. and Leonard, B.B (2017) Outboor cultivation of Scenedesmus obliquus BR003 in stirred Tanks by Air Lift. Journal of the Brazilian Association of Agricultural Engineering. V.37, N.5, 1041-1055.

13. Deise, P.T. Pabbo, D.G.; Leonardo, R.R.; Roberto, B.D.; Jurandir, P.F. and clandemir, M.R. (2017). Growth modeling of the green microalgae Scenedsmus obliquus in hybrid photobioreactor as a practical tool to understand both physical and biochemical phenomena in play during algae cultivation J. of Biotechnology and Bioengineering 115: 465-977). 

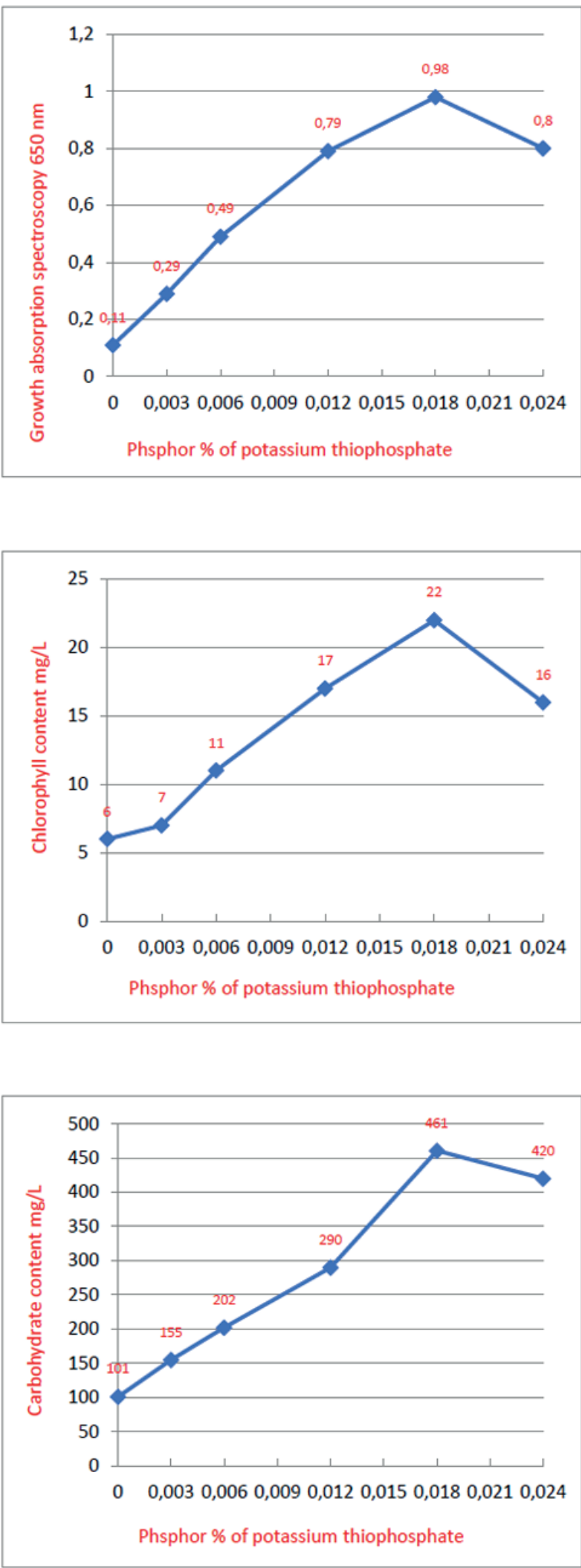

14. Marchin, T.; picum, M. and Frank, F. (2015). Photosynthesis of Scenedsmus obliques in outdoor open thin-layer cascade system in high and low coz in Belgium. Journal of Biotechnology 25: 1-14.

15. Chen, G.; and chen, F. (2006) growing phototrophic cells without light. Bioechnol. Lett., 28: 607-616.

16. Swati, Y.K.; Gayatri Gera, S. and Sanjay, K. (2017). Exploiting phosphate-starved cells of Scenedsmus SP. for the treatment of Raw sewage. Indian Journal Microbiology 57 (2) 241-249.
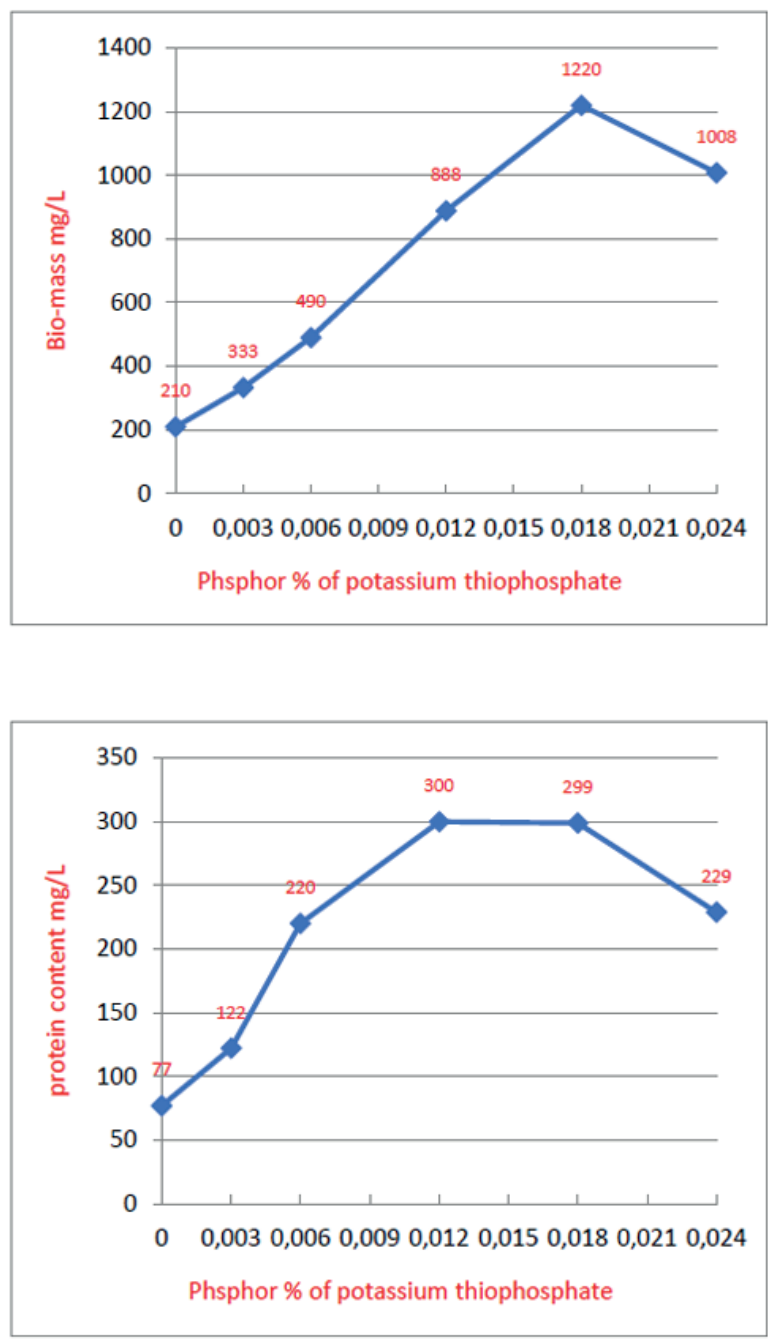

Figure 5. Influence the addition of different concentrations of potassium thiophosphate in the medium of sugar production plant wastes on growth, biomass, chlorophyll, protein, and carbohydrate content in the dark. Each value is an average of three frequencies.

17. Di caprio, F.; Altimari, P. and Pagnaneli F. (2015) Integrated biomass production and biodegradation of olive mill waste water by cultivation of Scenedsmus sp. Algal. Res. 9, 306-311.

18. Eustance, E.; Wray, J.T.; Badvipour, S.; Sommerfeld, M.R. (2016). The effect of cultivation depth, a real density, and nutrient level on lipid accumulation of Scendesmuse in outdoor raceway ponds. J. Appl. Phycol. 28-1459-1469. 

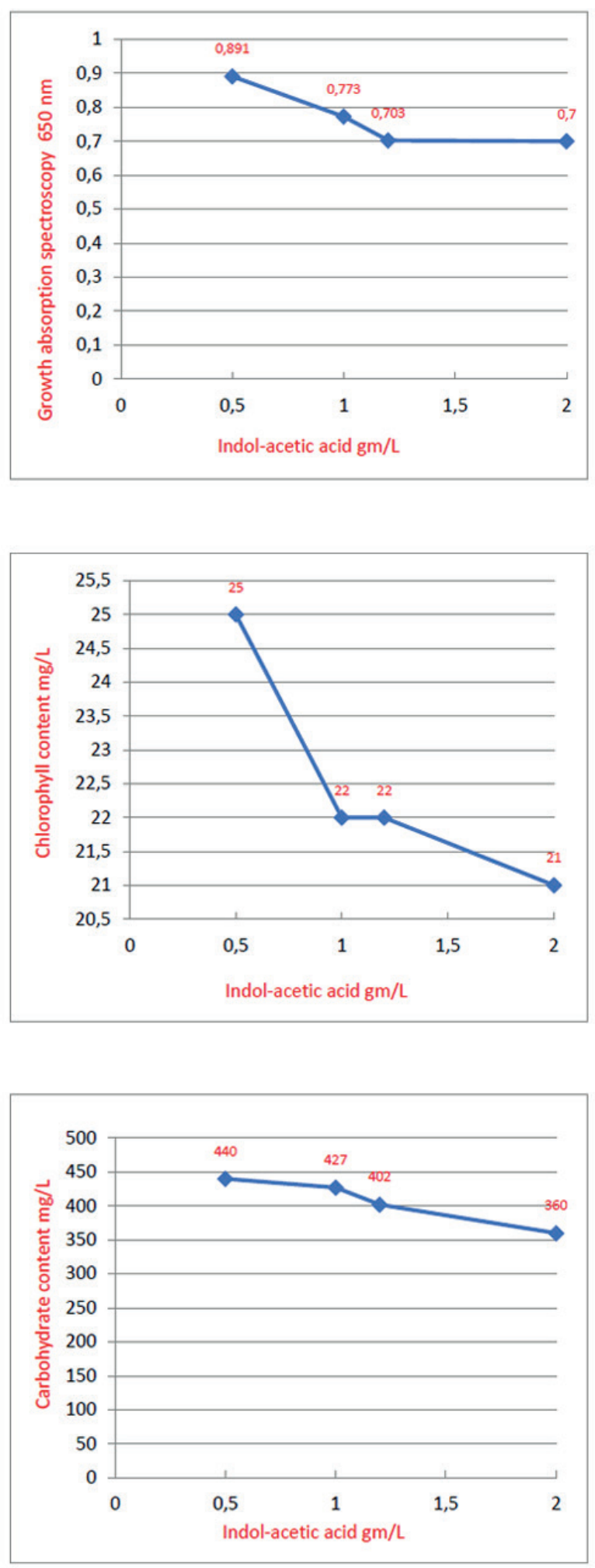

19. Shen, X. F.; Liu, J.; Chu, F.F.; Lam, P.K.; Zeng, R.J. (2015). Enhancement of FAME productivity of Scenedsmus obliquus by combining nitrogene deficiency with sufficient phosphorus supply in heterotrophic cultivation Appl. Energy. 158:348-354.

20. Edward, E.A. (2006). Ecology of harmful algae. University of New York--.

21. Xingfeng, H.; Huiru, Z., Pietro B.; Francesco, F. and Yunjnu, Y. (2018). Phytohormone and effects on growth and Metabolites of Microalage; A review. Fermentation 10: 4-25.
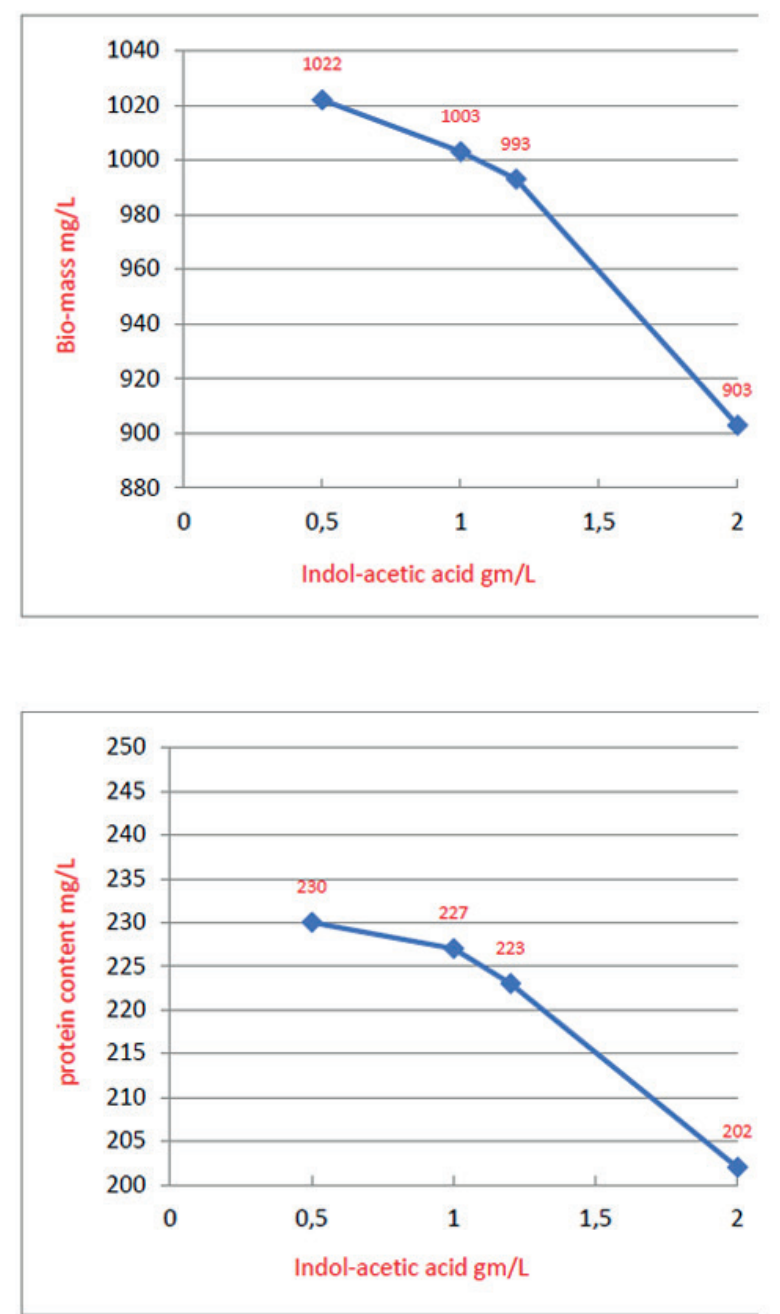

Figure 6. Influence the addition of different concentrations of IAA in the medium of the wastes of sugar production plant on the effectiveness of S. quadricuda in the dark. Each value is an average of three frequencies.

22. Ju, Y.G. (2015). Microalaga photobioreactor treatment domestic waste water and production biofuels. Master of Applied science. University - run Enterprises in China.

23. Czerpak, R., Krotke, A. and Mical, A. (1999). Comparison of stimulatory effect of auxin and cytokinins on protein, polysaccharides and chlorophylis content in Chlorella pyrenoidosa chicle. Pol. Arch. Hydrobiol. 46: 71-82. 

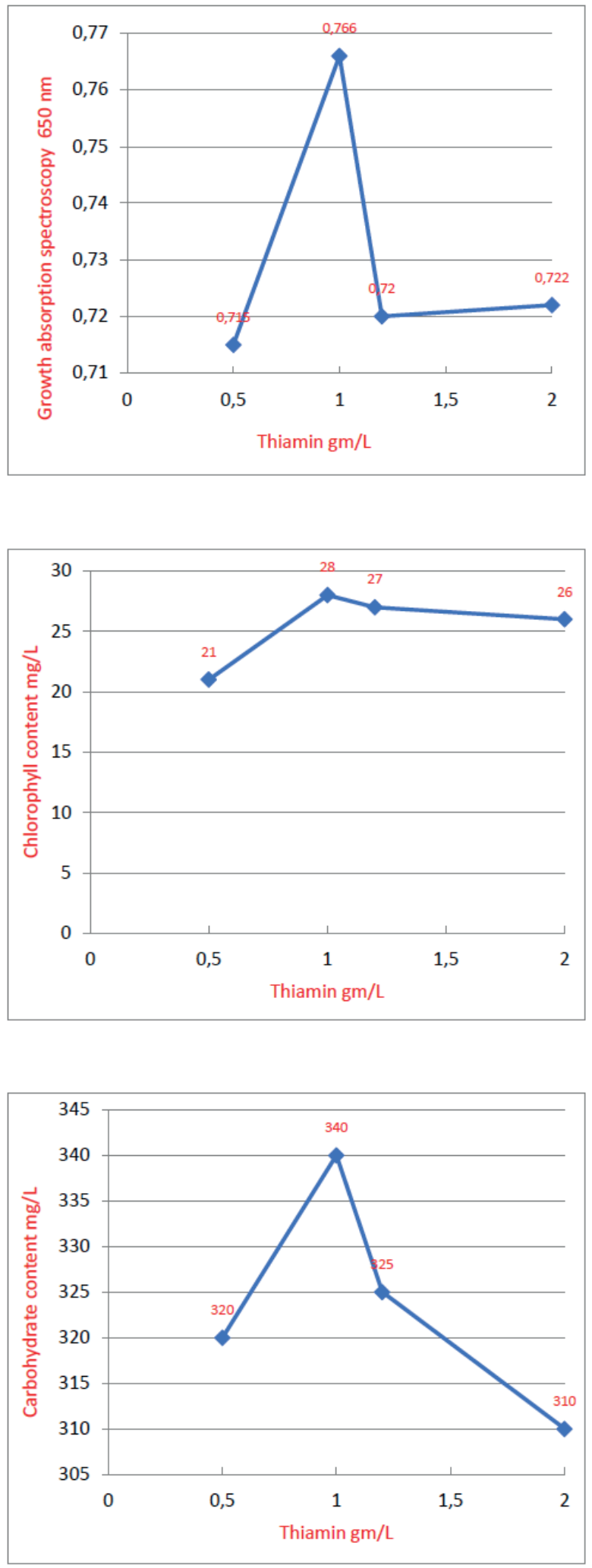

24.Puja, T.; Qiang, J. and Limin, H. (2017). A promising approach to enhance Microalgae productivity by exogenous supply of vitamins. Microb cell fact. 16/219: 2-13.

25. Desouky, S.A. (2011). Effect of some natural organic additivies on the growth and photosynthesis of pollution Chlorella vulgaris beijer. J. Appl. Sci. Res. 7: 23-

Received: 9 August 2021

Accepted: 21 September 2021
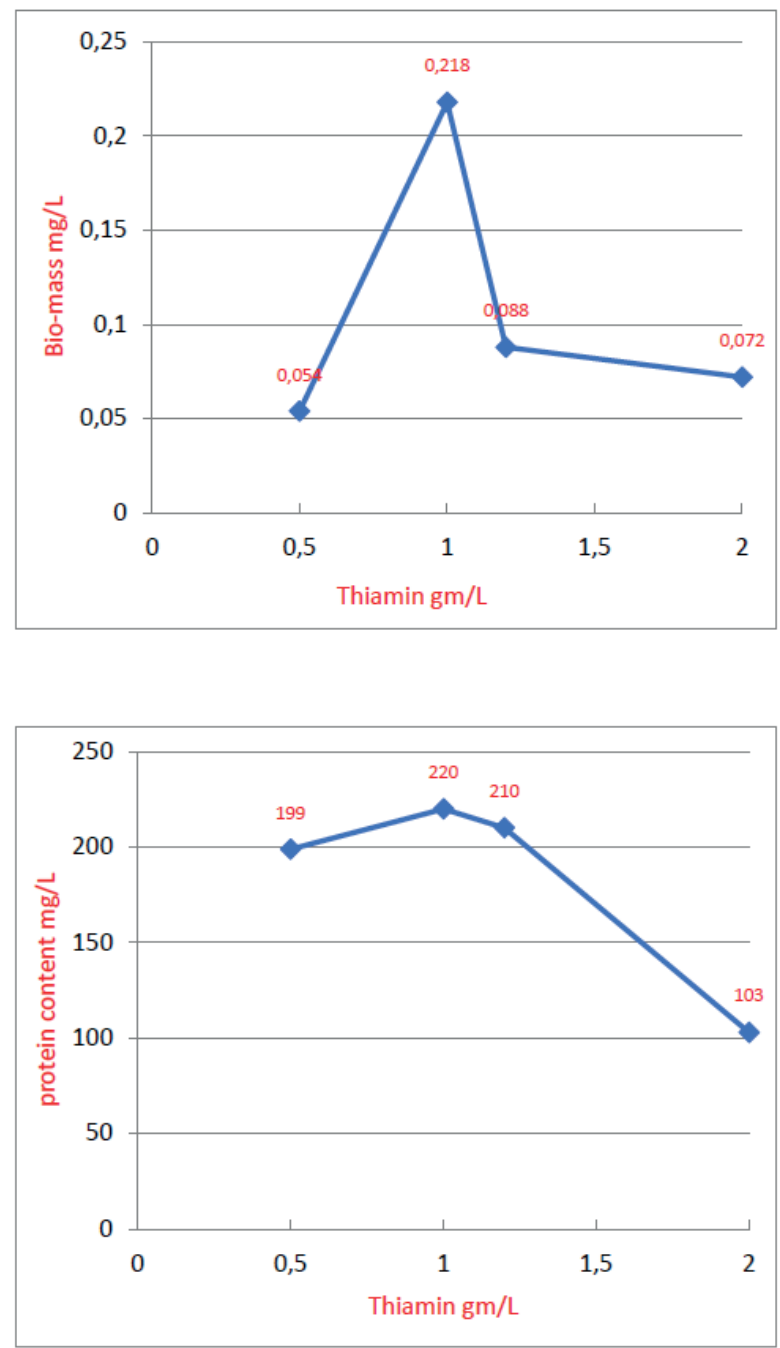

Figure 7. Influence the addition of different concentrations of thiamine in the wastes of the sugar production plant on the growth of S. quadricauda in the dark. Each value is an average of three frequencies. 